\title{
Advancing an Agenda for Women in Planning: An Epilogue
}

\author{
Natalie Osborne \\ Lecturer \\ School of Environment \\ Griffith University \\ Gold Coast, QLD, Australia \\ n.osborne@griffith.edu.au \\ Deanna Grant-Smith \\ Senior Lecturer \\ QUT Business School \\ Queensland University of Technology \\ Brisbane, QLD, Australia \\ deanna.grantsmith@qut.edu.au \\ Caryl Bosman \\ Associate Professor, Head of Planning Discipline \\ School of Environment \\ Griffith University \\ Gold Coast, QLD, Australia \\ c.bosman@griffith.edu.au
}

\begin{abstract}
This paper serves as an epilogue to the Women in Planning special issue of Australian Planner reflecting on the potential for women's activism and scholarship to promote social and spatial change around what have often been dismissed as irrelevant private or personal matters. This paper highlights the energy and willingness among women planners and those sympathetic to their goals toward seeking and creative positive and transformative change and engagement with issues of gender in planning. It specifically reports on the Women in Planning Symposium, held in Brisbane in 2016, and based on the principles of Appreciative Inquiry. Through this case we do not set out to 'prove' the impact of feminist approaches to planning or Appreciative Inquiry as applied in this workshop, rather, our goal here is to conclude this special issue by advancing an agenda for women in planning which is transformative, generative and pro-feminist and which has the potential to highlight and address gendered concerns in a productive way. We will reflect on both the findings that Appreciative Inquiry yielded, and on the process itself as a tool for participation and engagement, particularly in a feminist/emancipatory context.
\end{abstract}

Keywords: women in planning, gender, feminist planning, feminism, appreciative inquiry

\section{Introduction}

Feminism in planning, and indeed feminism more generally, has had an "uneven history" (Rahder \& Altilia 2004, 109). In the past "women's needs have too often been assumed to be identical 
with men's, or simply to be unworthy of note" (Hamilton and Jenkins 1989, 17) and too often planning has been approached as if it were a gender-neutral or 'gender-blind' concern. Women's activism, largely through engagement with other women, has often focussed on building individual strengths and leveraging them towards collective action, rather than emphasising individual behavioural solutions, to promote social change around what has often been "dismissed as irrelevant 'private matters'" (Home 1992, 154). When gendered spatial injustices arise, women's experiences of them have often been framed as "their own fault and not an urban structural issue" (Greed 1994, 43), or as resulting from their own personal choices, absent of structural influences. However, there is ample Australian and international evidence of women acting to take back their right to the city and the capacity to make decisions about their lives and their bodies, and using public spaces and streets to do so. An example of this is the SlutWalk movement created in Toronto, Canada in response to a victim-blaming student address by a police officer advising female students not to dress like sluts to avoid rape (Darmon 2014). Locally and independently organised SlutWalks have taken place in more than forty countries as a strategy of direct resistance to misogynist victim-blaming, sex-shaming and patriarchal control of women's bodies and sexualities (Carr 2013) and the idea that women are somehow responsible for their own victimisation. Although there is a visible online presence to these movements (Darmon 2014) it is their embodied protest and physical presence that has dominated the imaginary.

There have been some critiques of SlutWalk for failing to acknowledge intersectionality and the unevenness in terms of who is able to or interested in appropriating the term 'slut', and for centring white and cis- positionalities and experiences (Bogando 2011; McNicol 2015), or for simply replicating "prevailing heterosexual male fantasy" (O'Keefe 2014, 8) and doing little to challenge misogynist norms. Yet, as O'Keefe $(2014,3)$ observes "to name the location and significance of the body to protest is to also understand the ways in which power contestations are played out via the body". Indeed, "the gendered body in protest can be used to manipulate, challenge and seize the power that seeks to confine and define it" (O'Keefe 2014, 4). In taking these protests to the streets, protesters were linking their embodied experiences to public space. 
SlutWalk is an act of claiming one's belonging to the public sphere, as well as challenging the policing of women's bodies and appearances, and our subjection to the heteronormative male gaze when in that sphere.

A further example of embodied protest can be seen in the \#IllRideWithYou campaign following the 2014 Martin Place shooting in Sydney (Australia). In a movement that began with Rachael Jacobs, in Brisbane (Australia), and Sydney-based Twitter user Sir Tessa (@sirtessa) (Jacobs 2014), many individuals recognised that Muslim people-particularly Muslim women who wear religious attire-would face increased danger on public transport as a result of heightened bigotry and hatred following the shooting perpetrated by a self-identified Muslim man. Using the hashtag, "\#IllRideWithYou", people offered themselves as escorts on specific public transport routes for Muslim commuters and travellers who were concerned about the increased risk to their safety as a result of this incident. While this campaign was a moving display of support for the Australian Muslim community it also served to highlighted the increased danger that women and minority travellers face while using public transport, and the fact that public spaces are more or less safe (or perceived to be so) depending on one's positionality and identity (Grant-Smith, Osborne \& Marinelli 2016). These concerns have been echoed in other actions designed to draw attention to women's (and others') right to the city and right to be safe such as the 'reclaim the night' rallies and 'take back the night' rallies often organised in response to violence again women (McLean and Maaslen 2013).

These brief examples demonstrate the potential for collective action to highlight and address women's issues, and how many feminist struggles have had an explicitly spatial dimension - a feminist spatial politics linked to everyday and embodied experiences. That 'planning is political' is something of a cliché, but it cannot be denied that the processes that produce urban space also reflect and (re)produce social relationships. Ergo, the everyday practices of planners are inextricably imbued with the potential to either reinforce existing gendered spatial subjugation and politics, or to transform our cities and our social relationships in more emancipatory and just ways. 


\section{Planning Transformed?: reflections from the Women in Planning symposium}

The remainder of this paper reflects on the 2016 Women in Planning Symposium, held in Brisbane, Australia. Mirroring its theme-"women in planning: planning transformed" —the intention of the symposium was to focus on positive achievements of and for women in planning, and to foster a (gender) politics of hope in the planning community. The symposium was attended by a range of participants including academics, practicing planners, students, and community members; the vast majority of whom were women. ${ }^{1}$ Participation by members of the Planning Institute of Australia attracted professional development points.

The symposium was full day event, comprising a keynote by Professor Carolyn Whitzman, several panel sessions of varied formats, and a workshop in the afternoon. The workshop delivery adapted Appreciative Inquiry from its roots in organisational change and behaviour (Bushe 2011) by treating it as a tool for feminist-based action research, which resonated with the researchers' experiences and the philosophy underpinning the symposium. The application of the method used delivery techniques akin to a collaborative, community planning workshop, which would have been familiar to most participants.

\section{An overview of Appreciative Inquiry}

Appreciative Inquiry as a process seeks to engage stakeholders in self-determined change (Carter 2006; Yoder 2005) through the creation of a shared generative metaphor or imaginary that compels action (Bushe \& Kassam 2005). Although Appreciative Inquiry is not rooted in emancipatory axiology or politics, it may be broadly compatible with feminist research methodologies as both centre participants as co-creators of knowledge, and challenge both the hierarchical relationships between 'creators' of knowledge/strategies and 'end users' of knowledge/strategies and the existence of that dichotomy. Both approaches emphasise the value of centering those who are experiencing phenomena at the heart of any transformative process

\footnotetext{
${ }^{1}$ The Women in Planning Symposium was advertised as being welcome to all genders, but few men attended. This unfortunately reflects the common assumption that gender equity - and indeed other forms of justice for those marginalised in planning - is "women's work".
} 
and seek to subvert existing power relationships through a commitment to broadening the scope of who is able and empowered to act (See Bushe 2011; Bushe and Kassam 2005; Harding 2004; Wylie 2003).

Appreciative Inquiry advances a shift from problem-centric approaches which work within norms without changing them, to an opportunity-centric approach which has the potential to reframe and dramatically shift them (Boyd \& Bright 2007). It has been argued that, "feminists are sometimes accused of clinging to past grievances" (Rahder \& Altilia 2004, 111); however Appreciative Inquiry approaches change by focusing on successes and highlighting the best of what already is and what is already working, to develop a shared, co-constructed vision and action plan among participants (Carter 2006). Though of course, sometimes sharing grief over painful experiences is a necessary and valuable process that enables moving forward. Despite this emphasis, Appreciative Inquiry does not focus solely on the positive (Boje 2010), rather, it rejects a problem or deficit-focused orientation.

Generative theory in Appreciative Inquiry signifies a constructionist ontology, one in which 'words create worlds' and where changing one's understanding can generate transformative change in the fabric of our worlds (Bushe 2011; Carter 2006; Cooperrider et al. 1995). Herein, groups, organisations, and other structures are viewed as made, as co-constructed through social relationships, and they can thus be re-made (Cooperrider et al. 1995). Words and narratives are imbued with constitutive significance in a constructionist worldview. As such, much of the focus in Appreciative Inquiry is placed upon the words and stories used and shared, acknowledging, "the language of the inquiry has important outcomes in and of itself" (Bushe \& Kassam 2005, 166). Further, the way the future of an issue, organisation, or indeed city is talked about and imagined is linked to how it will be (Bushe and Kassam 2005; Carter 2006).

Appreciative Inquiry often operates based on an heliotropic understanding of individuals and social systems (Cooperrider 1990) which assumes that in the same way that plants are drawn toward light, individuals are drawn toward hope and "the most positive images they hold of themselves" (Enright et al. 2014, 918). Of course, we are often unused to focusing on what we do 
well, and that can be a challenge when implementing an Appreciative Inquiry process (Carter 2006).

Critical strengths of an Appreciative Inquiry approach is that it can "build rapport and energy" (Bushe 2007, 3), foster partnerships and develop pathways for and capacity to collaborate (Carter 2006). It is further argued that Appreciative Inquiry may "take better care" (Liebling, Elliott \&Arnold 2001, 164) of participants involved in the process, which may resonate with researchers and practitioners familiar with feminist-based methodologies that adopt an ethic of care (Collins 1989; Edwards \& Mauthner 2002). Through its focus on shared personal narratives, and acknowledging strengths and assets, an Appreciative Inquiry approach can also promote trust, respect, hope, and collaboration and increase participants' feelings of empowerment and leadership capabilities (Calebrese et al. 2010). Because Appreciative Inquiry promotes innovation and collaboration through participatory methods (Boyd \& Bright 2007) it has been used extensively in community development (Akdere 2005), especially asset based community development. It has also been suggested that Appreciative Inquiry is particularly suited to women's preferred modes of communication (Sekerka et al. 2006). It is for these reasons that the workshop component of the Women in Planning Symposium was built around an Appreciative Inquiry process.

\section{The Appreciative Inquiry Workshop}

Appreciative Inquiry is often structured around a series of workshops that may take place over a period of days or weeks, which of course we were unable to replicate in this context. That said, following Oliveira (2012) a five-step Appreciative Inquiry process was applied. 
The definition phase comprised the first half of the symposium in which a number of speakers were invited to share stories of their experiences as women in planning. These stories were oriented toward celebration and presentations grouped around a number of themes: mentoring \& making opportunities; creating synergies; politics \& planning for inclusion; and getting things done at the local level. Participants were also invited to share their stories through a roving videographer or by completing postcards and placing these on a clothesline for others to read (image 1). The postcards posed provocative statements such as: 'what women in planning means to me...', 'my aspiration for women in planning is...', and 'women in planning matters because....'. The purpose of these speakers and activities was to begin to orient participants toward an appreciative stance.

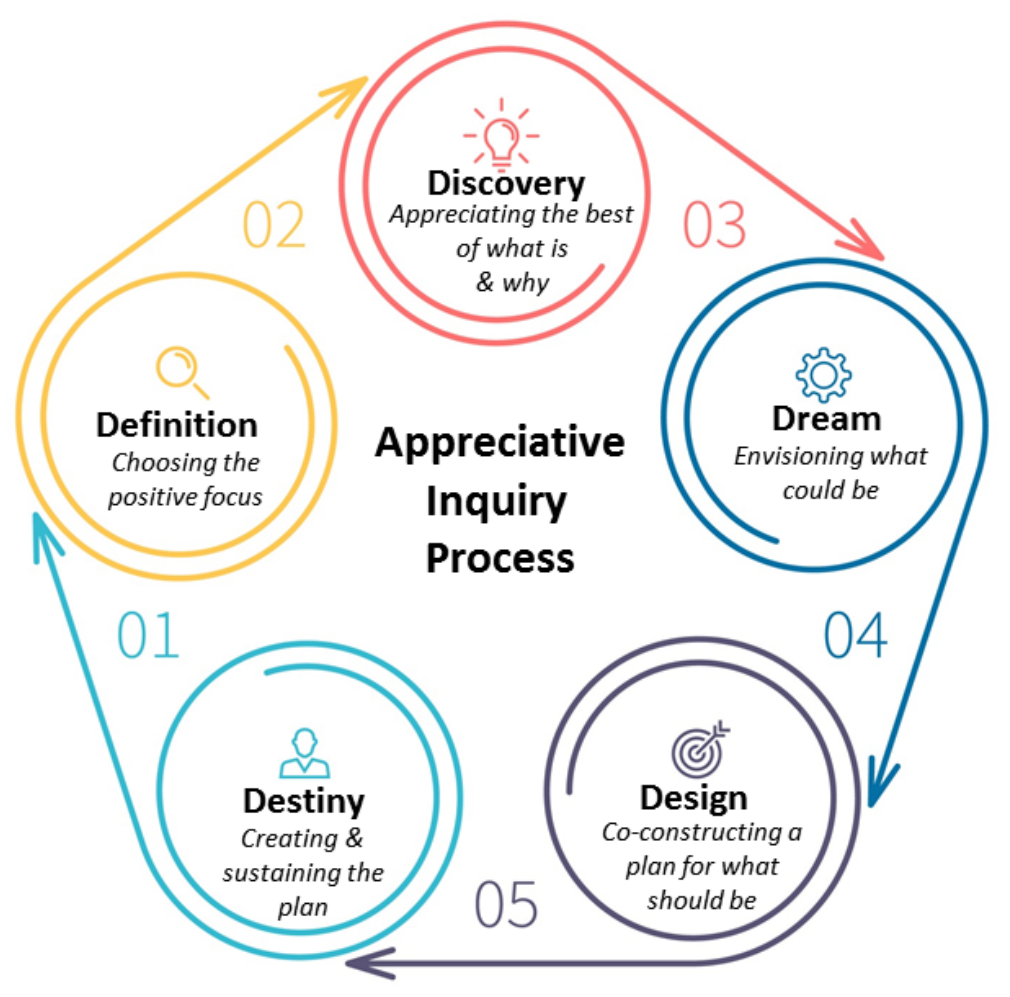

Figure 1. Women in Planning Symposium Appreciate Inquiry Process 


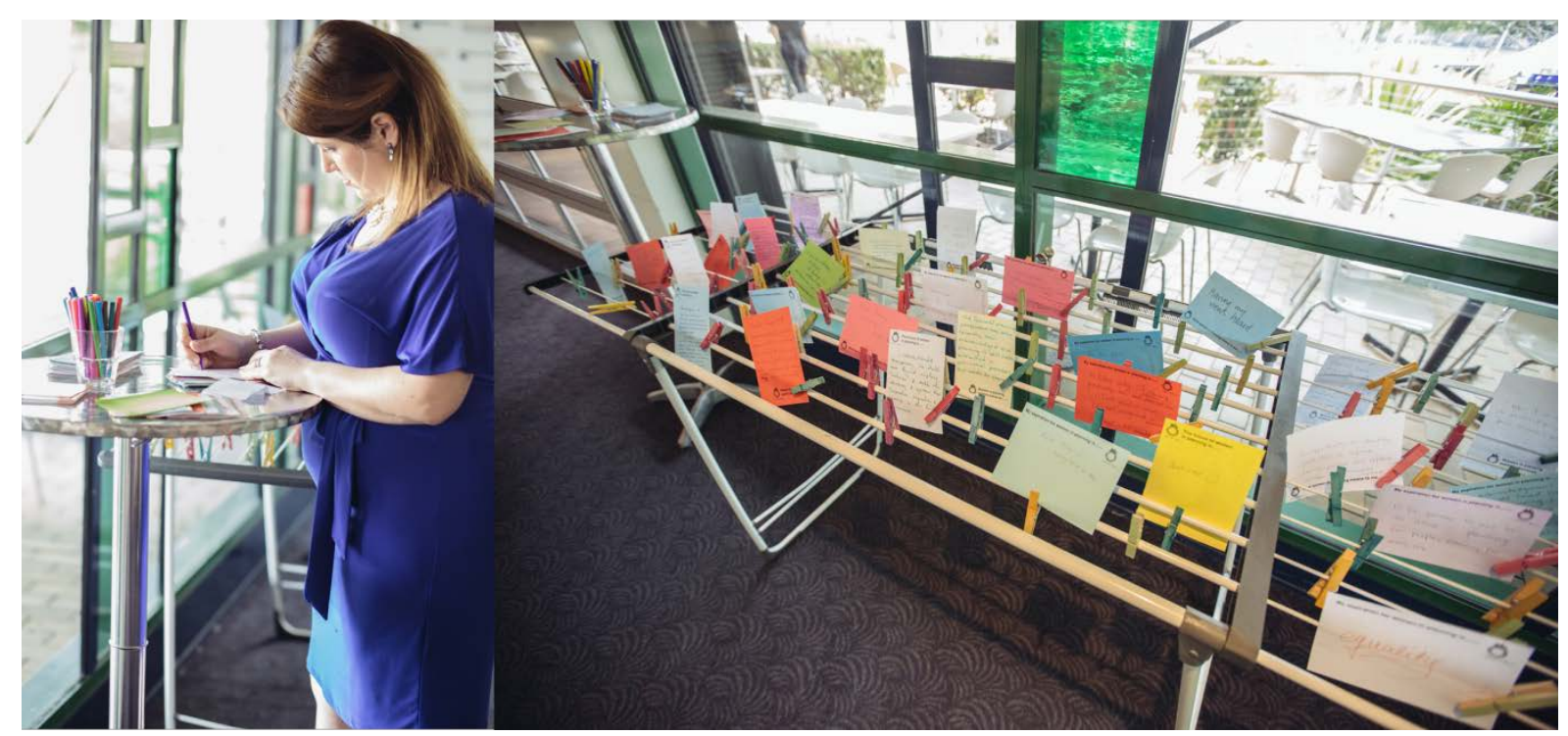

Image 1. Completed postcards at the Women in Planning Symposium

The afternoon of the symposium was dedicated to working through the final four steps of the Appreciative Inquiry process. Participants formed small groups and worked through a set of four questions, which corresponded to the remaining steps of the Appreciative Inquiry process. The questions were designed to be reasonably generic, given that participants had come from different sectors and organisations, and engaged with planning and spatial politics in a variety of ways.

At the discovery stage, participants were asked to explore the best of, and in, what is (Bushe 2011), by interviewing each other about their experiences and opinions (Bushe 2011; Carter 2006) and by sharing stories (Bushe \& Kassam 2005). The prompt question was: what are we doing well when it comes to gender equity (and diversity more generally)?

Participants were then asked to engage with the dream stage which focusses on developing a shared vision and sense of strategic possibilities - i.e., what if there was more of the best of what currently is - through words, imagery, and/or graphics (Bushe 2011; Carter 2006; Coghlan et al. 2003). The prompt question was: In terms of gender and diversity, what would a more just city look like? What would a more equitable profession look like?

The design stage comprised the development of proposals, or design elements, that enable the achievement of the shared vision/dream (Bushe 2011). This stage is grounded in the possible because it is founded on what already is and builds from there. The prompt question 
was: How can we act to improve gender equity (and diversity more generally) in and through the built environment, and within the profession?

Participants were also encouraged to commit themselves to taking action in an area that resonates with their values and priorities - the destiny stage of Appreciative Inquiry. The prompt question was: What are the steps that you will take tomorrow to progress this agenda? These ideas were shared with the broader group to conclude the symposium.

Our intention in using Appreciative Inquiry at the symposium was not to develop a formal structure or process for implementation of these actions, indeed, rigid, formal approaches are considered anathematic to Appreciative Inquiry. Rather, the purpose was to motivate and nurture the self-organised actions of participants (Bushe 2011) to produce a shared imaginary of a collective future, and the healing and relationship building that are facilitated through developing that shared imaginary (Carter 2006). It was also about fostering a sense of appreciation for and amongst each other - essential for maintaining and progressing a gendered spatial politics of hope.

\section{Tensions and possibilities in Appreciative Inquiry}

A tension in the use of Appreciative Inquiry is that it emphasises positivity and strengths, positioning itself as 'non-deficit' in contradistinction to more traditional 'problem-solving' approaches to change (Carter 2006; Yoder 2004). Yet there would be little motivation for undertaking an Appreciative Inquiry process unless there were problems or concerns in need of being addressed - indeed, we would hardly devote time to organising a Women in Planning Symposium, or indeed a Women in Planning Special Issue, if we felt that gender was not an issue in planning. Some scholars navigate this by arguing that rather than dichotomising positive and negative, Appreciative Inquiry is about eliciting a feeling of goodness and goodwill within us, and generating possibilities and change in that transformative moment (Bushe 2011). Therefore, a key challenge for us in implementing an Appreciative Inquiry approach was finding ways to frame appreciative questions, as our research training as critical feminist scholars has prepared us to look for problems, and to engage in exhaustive (sometimes exhausting) problematisation. Despite this tension, the discussions within the groups were highly productive, and the various 
contributions to the symposium suggested a high degree of optimism for the future. In fact, there was considerable energy for continuing the conversations begun at the symposium, and some likelihood of another symposium to be held in a different city in 2017.

An additional tension is that Appreciative Inquiry can be seen as uncritical, even hostile to critical theory, as such practices can be denigrated or dismissed as problematically 'deficit' oriented and therefore unproductive and to be eschewed (Boje 2010). Our linking of an explicitly feminist methodology and Appreciative Inquiry could be controversial in this light, given feminism is a branch of critical theory. Further, it would be irresponsible and unjust to ask victims of workplace harassment, for instance, to focus only on what's positive about their employer, and avoid discussing their experiences and the harm done to them. As with all things, context and purpose matters. Appreciative Inquiry is a flexible framework (Carter 2006) and can be applied in contextually situated ways. 'Negative' stories may still—and arguably, in some contexts, should— emerge (Carter 2006). Indeed, our Symposium participants' hopeful accounts were tempered by historical and ongoing experiences of discrimination in the profession which, mirroring contributions to this special issue, suggest that our workplace behaviours, opportunities and experiences of and in planning continue to be constrained by gendered norms and expectations.

Further, as this case has shown, it should be recognised that feminist approaches, while critical, are not necessarily negative or restrictive; many seek to promote and facilitative positive change, advance a politics of hope, and have explicitly emancipatory aims. An Appreciative Inquiry approach can assist these aims by promoting constructive conflict and critique due to its future orientation. Symposium contributions reflected aspirations for empowerment and equality and a strong desire to (re)engender an ethics of care in the planning profession. Although there was insufficient time to create a collaborative framework for action, ultimately the Appreciative Inquiry process did provide some structure for collaborative and inclusive small-group discussions, and may have planted 'seeds' for further action and a sense of camaraderie based on working differently, but in concert, toward a common goal and shared vision. 


\section{Conclusion: Nurturing a nascent politics of hope and possibility}

Rahder and Altilia (2004) lament that despite many contributions, feminism has not managed to retain a foothold in planning discourse, and has been met with claims that "that the feminist project [is] successful, and complete" (111). Yet our cities and towns are still gendered landscapes, and planning is only beginning to grapple with the complexities of intersectionality. In recent decades there has been a spatial turn in other fields (Shaw 2016) - including humanities, political science and sociology - linking justice and emancipation, critical theory, feminism, critical race theory, Marxism, anarchism, and/or decolonisation with issues of space and place, and planners and geographers can make and are making vital contributions to these conversations. We are far from spatial justice, and it is the task of planners to continue to interrogate and challenge the spatial (re)production of power, privilege, and marginality of those belonging to particular identity groups and positionalities. The feminist project has been successful in many ways, but it is not complete, and we are not yet living in the Just City. We are not done.

Yet the contributions to the Women in Planning Symposium, and to this Special Issue of Australian Planner, demonstrate that, although we are not done, we are also not labouring alone. There remains energy, willingness, and capacity for creative, positive and transformative change for just cities, for engaging with issues of gender and equity in planning, and for nurturing the nascent politics of hope and possibility (Cameron 2007) in planning education, research, and practice.

\section{Acknowledgements}

The authors would like to acknowledge the efforts of Caryl Bosman for leading the Women in Planning Symposium and this special issue. The authors also acknowledge the contributions of all speakers and the Women in Planning Symposium: Brittany Lauga MP, Carolyn Whitzman, Carolyn Vincent, Dianne Dredge, Donnell Davis, Kellie Burns, Kirsty Kelly, Laurel Johnson, Madonna Thomas, Nicole Laffoley, and Stephanie Wyeth. Thanks are also extended to Blake Morgan, Rachael Cole-Hawthorne, and Merrill Bowers for administrative and other support at the Symposium, and to Renee Chapman of Renee Chapman Photography for her interviewing, 
filming and photography on the day. Financial support for the Women in Planning Symposium was provided by the Queensland Government's Advance Queensland Fund, QUT Work/Industry Futures Research Program, University of Queensland, and Griffith University.

\section{References}

Akdere, M. 2005. "Appreciative inquiry: a field study of community development." Systemic Practice and Action Research, 18(1): 21-34. DOI: 10.1007/s11213-005-2457-5

Boje, D.M. 2010. "Side shadowing appreciative inquiry: one storyteller's commentary." Journal of Management Inquiry, 19(3): 238-241. DOI: 10.1177/1056492610369627

Boyd, N.M. \& Bright, D.S. 2007. "Appreciative inquiry as a mode of action research for community psychology" Journal of Community Psychology, 35(8): 1019-1036. DOI: 10.1002/jcop.20208

Bushe, G.R. 2001. "Five theories of change embedded in appreciative inquiry." In Appreciative Inquiry: An Emerging Direction for Organization Development, edited by D. Cooperrider, P. Sorenson, D. Whitney, \& T. Yeager, 117-127. Champaign: Stipes.

Bushe, G.R. 2007. "Appreciative inquiry is not (just) about the positive." OD Practitioner, 39(4): 3338.

Bushe, G.R. 2011. "Appreciative inquiry: Theory and critique." In The Routledge Companion to Organizational Change, edited by D. Boje, B. Burnes, and J. Hassard, 87-103. Oxford: Routledge.

Bushe, G.R. \& Kassam, A.F. 2005. "When is appreciative inquiry transformational? A meta-case analysis." The Journal of Applied Behavioral Science, 41(2): 161-181. DOI: 10.1177/0021886304270337

Calabrese, R., Hester, M., Friesen, S. \& Burkhalter, K. 2010. "Using appreciative inquiry to create a sustainable rural school district and community." International Journal of Educational Management, 24(3): 250-265. DOI: 10.1108/09513541011031592

Cameron, J. 2007. "Teaching a politics of hope and possibility." Key note presentation to SocCon 2007: National Conference of New Zealand Social Science Teachers. Retrieved from: http://www.communityeconomies.org/site/assets/media/old\%20website\%20pdfs/Papers/ on\%20rethinking\%20the\%20economy/Teaching\%20a\%20Poltics\%20of\%20Hope\%20and \%20Possibility.pdf

Carr, J.L. 2013. "The SlutWalk movement: A study in transnational feminist activism." Journal of Feminist Scholarship, 4(1): 24-38.

Carter, B. 2006. "'One expertise among many': working appreciatively to make miracles instead of finding problems-Using appreciative inquiry as a way of reframing research." Journal of Research in Nursing, 11(1): 48-63. DOI: 10.1177/1744987106056488 
Coghlan, A.T., Preskill, H. \& Tzavaras Catsambas, T. 2003. "An overview of appreciative inquiry in evaluation." New Directions for Evaluation, 2003 (100): 5-22. DOI: 10.1002/ev.96

Collins, P.H. 1989."The Social Construction of Black Feminist Thought." Signs, 14(4): 745-773.

Cooperrider, D.L. 1990. "Positive image, positive action: The affirmative basis of organizing." In Appreciative Management and Leadership, edited by S.Srivastva \& D.L. Cooperrider,91125. San Francisco: Jossey-Bass.

Cooperrider, D.L., Barrett, F. \& Srivastva, S. 1995. "Social construction and appreciative inquiry: a journey in organizational theory", in Management and Organization: Relational Alternatives to Individualism, edited by D. Hosking, H.P. Dachler, \& K. Gergen, 157-200. Ashgate Publishing.

Darmon, K. 2014. "Framing SlutWalk London: How does the privilege of feminist activism in social media travel into the mass media?" Feminist Media Studies, 14(4): 700-704. DOI: $\underline{10.1080 / 14680777.2014 .935208}$

Edwards, R. \& Mauthner, M. 2002. "Ethics and feminist research: Theory and practice." In Ethics in Qualitative Research, edited by M. L. Mauthner, M. Birch, J. Jessop \& T. Miller, 14-31. London: SAGE Publications.

Enright, E., Hill, J., Sandford, R., \& Gard, M. 2014. "Looking beyond what's broken: towards an appreciative research agenda for physical education and sport pedagogy." Sport, Education and Society, 19(7), 912-926. DOI: 10.1080/13573322.2013.854764

Grant-Smith, D., Osborne, N., \& Marinelli, P. 2016. "Transport and workplace accessibility: Routes to improved equity In Overcoming Challenges to Gender Equality in the Workplace: Leadership and Innovation, edited by P. M. Flynn, K. Haynes, and M. A. Kilgour, 107-123. Sheffield: Greenleaf Publishing.

Greed, C. 1994. Women and Planning: Creating Gendered Realities. London: Routledge. Hamilton, K. \& L. Jenkins. 1989. "Why women and travel?" In Gender, Transport and Employment: The Impact of Travel Constraints, edited by M. Grieco, L. Pickup \& R. Whipp, 17-45. Aldershot: Averbury.

Harding, S. 2004. "The Logic of a Standpoint." In The Feminist Standpoint Theory Reader: Intellectual and Political Controversies, edited by S. Harding, 17-20. New York: Routledge.

Home, A. M. 1992. "Mobilizing women's strengths for social change: The group connection." Social Work with Groups, 14(3-4): 153-173.DOI: 10.1300/J009v14n03 12

Liebling, A., Elliott, C. \& Arnold, H. 2001. "Transforming the prison: Romantic optimism or appreciative realism?" Criminology and Criminal Justice 1(2): 161-180. DOI: $10.1177 / 1466802501001002002$

Jacobs, R. (2014, December 16). "How \#illridewithyou began with Rachael Jacobs' experience on a Brisbane train." Brisbanetimes.com.au. Retrieved from http://www.brisbanetimes.com.au/queensland/how-illridewithyou-began-with-rachaeljacobs-experience-on-a-brisbane-train-20141216-128205.html 
McLean, J., \& Maalsen, S. 2013. Destroying the joint and dying of shame? A geography of revitalised feminism in social media and beyond. Geographical Research, 51(3): 243-256. DOI: 10.1111/1745-5871.12023

McNicol, L. (2015). "A Critical Reading of SlutWalk in the News: Reproducing Postfeminism and Whiteness." In Feminist Erasures: Challenging Backlash Culture, edited by K. Silva \& K. Mendes, 235-257. London: Palgrave Macmillan.

Oliveira, R. R. 2012. "Investigação Apreciativa em Organizações Não Governamentais e Planejamento Estratégico: Discussão Teórico-Empírica de um Estudo." Administração Pública e Gestão Social, 4(2):172-201.

O'Keefe, T. 2014. "My body is my manifesto! SlutWalk, FEMEN and femmenist protest." Feminist Rreview, 107(1): 1-19. DOI: 10.1057/fr.2014.4

Rahder, B., \& Altilia, C. 2004. "Where is feminism in planning going? Appropriation or transformation?" Planning Theory, 3(2): 107-116. DOI: 10.1177/1473095204044777

Sekerka, L. E., Brumbaugh, A. M., Rosa, J. A. \& Cooperrider, D. 2006. “Comparing appreciative inquiry to a diagnostic technique in organizational change: The moderating effects of gender." International Journal of Organization Theory and Behavior, 9(4): 449-489.

Shaw, D.B. 2016. "Introduction: Radical Space" in Radical Space: Exploring politics and practice, edited by D.B. Shaw and M. Humm, xiii-xxv. London: Rowman \& Littlefield.

Wylie, A. 2003. "Why Standpoint Matters." In Science and Other Cultures: Issues in Philosophies of Science and Technology, edited by R. Figueroa \& S. Harding, 26-48. New York: Routledge.

Yoder, D.M. 2004. "Organizational climate and emotional intelligence: an appreciative inquiry into a 'leaderful' community college." Community College Journal of Research and Practice, 29(1): 45-62. DOI: 10.1080/10668920390276966 